\title{
Feeding reduced-fat dried distillers grains with solubles to lactating Holstein dairy cows does not alter milk composition or cause late blowing in cheese
}

\author{
E. D. Testroet, ${ }^{\star}$ D. C. Beitz,† M. R. O’Neil,† A. L. Mueller,† H. A. Ramirez-Ramirez,† and S. Clark $\S^{1}$ \\ *Department of Animal Sciences, Washington State University, Pullman 99164 \\ †Department of Animal Science, lowa State University, Ames 50011 \\ †Purina Animal Nutrition, Rochester, MN 55904 \\ §Department of Food Science and Human Nutrition, lowa State University, Ames 50011
}

\begin{abstract}
Feeding dried distillers grains with solubles (DDGS) to lactating dairy cows has been implicated as a cause of late blowing defects in the production of Swiss-style cheeses. Our objectives were (1) to test the effect of feeding reduced-fat DDGS (RF-DDGS; $\sim 6 \%$ fat) to lactating dairy cows on the composition of milk and on the suitability of the milk for production of baby Swiss cheese and (2) to evaluate the effect of diet on cow lactation performance. Lactating Holstein dairy cows were fed both dietary treatments in a $2 \times 2$ crossover design. Cows were housed in a 48-cow freestall pen equipped with individual feeding gates to record feed intake. The control diet was a corn, corn silage, and alfalfa hay diet supplemented with mechanically expelled soybean meal. The experimental diet was the same base ration, but 20\% (dry matter basis) RF-DDGS were included in place of the expelled soybean meal. The RF-DDGS diet was additionally supplemented with rumen-protected lysine; diets were formulated to be isoenergetic and isonitrogenous. Cows were allowed ad libitum access to feed and water, fed twice daily, and milked 3 times daily. For cheese production, milk was collected and pooled 6 times for each dietary treatment. There was no treatment effect on milk yield (35.66 and 35.39 $\mathrm{kg} / \mathrm{d})$, milk fat production (1.27 and $1.25 \mathrm{~kg} / \mathrm{d})$, milk fat percentage $(3.65$ and $3.61 \%)$, milk protein production $(1.05$ and $1.08 \mathrm{~kg} / \mathrm{d})$, lactose percentage (4.62 and $4.64 \%$ ), milk total solids (12.19 and $12.28 \%$ ), and somatic cell count $\left(232.57\right.$ and $287.22 \times 10^{3}$ cells $\left./ \mathrm{mL}\right)$ for control and RF-DDGS, respectively. However, dry matter intake was increased by treatment, which implied a reduction in feed efficiency. Milk protein percentage also increased (3.01 and 3.11\%), whereas milk urea nitrogen decreased (14.18 and $12.99 \mathrm{mg} / \mathrm{dL}$ ), indicating that protein utilization may be more efficient when
\end{abstract}

Received August 17, 2017.

Accepted March 4, 2018.

${ }^{1}$ Corresponding author: milkmade@iastate.edu cows are fed RF-DDGS. No differences in cheese were observed by a trained panel except cheese appearance; control cheese eyes were significantly, but not practically, larger than the RF-DDGS cheese. These results indicate that RF-DDGS can be effectively used in the rations of lactating Holstein cows with no deleterious effects on milk production and composition and metrics of the physiology of the cow (i.e., blood glucose and nonesterified fatty acids); however, feeding RF-DDGS increased dry matter intake, which decreased feed efficiency. Finally, feeding RF-DDGS did not negatively influence quality and suitability of milk for production of baby Swiss cheese.

Key words: efficiency, dried distillers grains with solubles, milk fat, protein utilization, sensory

\section{INTRODUCTION}

Feeding of conventional corn dried and wet distillers grains with solubles (DG) to ruminant animals has been studied and reviewed extensively (Klopfenstein et al., 2008; Schingoethe et al., 2009). However, some studies with lactation dairy cows report no changes in production metrics (Anderson et al., 2006; SasikalaAppukuttan et al., 2008), whereas others report either positively or negatively altered milk composition or yield when DG are fed (Kleinschmit et al., 2006; Abdelqader et al., 2009). The discrepancies in results indicate that several factors influence milk production when incorporating DG in the rations and that there may be limitations that need to be considered. One problem with feeding conventional DG is that they contain approximately $13 \%$ ether extract, which comprises mainly corn oil, a rich source of UFA. This problem is multifaceted; inclusion of DG can result in diets that can exceed 5\% lipid (DM basis), which can hinder fiber digestion (Zinn, 1989) due to toxic effects of rumen microbes (Maia et al., 2007) and altered biohydrogenation of UFA in the rumen. It is believed that ruminal microbes have a great capacity to reduce unsaturated hydrocarbons as a way to reduce the toxicity of UFA. 
Incomplete biohydrogenation of these hydrocarbons, however, can result in the production of bioactive forms of CLA, such as trans-10,cis-12 CLA, which inhibit de novo lipogenesis in the mammary gland (Baumgard et al., 2001). In addition, trans-10,cis-12 CLA is a bioactive compound that can decrease mRNA encoding for proteins important to mammary uptake of preformed fatty acids (Peterson et al., 2003). The aforementioned problem can result in milk fat depression, a condition characterized by decreased milk fat concentration and yield without concomitant alteration in milk yield or concentrations of other milk components (Bauman and Griinari, 2001). Recent modifications in oil extraction from DG (Majoni et al., 2011) for the biodiesel industry have led to the production of reduced-fat dried distillers grains with solubles (RF-DDGS), thus limiting availability of conventional dried distillers grains with solubles (DDGS). Currently, unless the value of corn oil decreases, it is not likely that conventional DDGS will be readily available and that-RF-DDGS will be the predominant co-product of the ethanol industry as a protein source (Pritchard, 2010). The decreased oil content of RF-DDGS could be an advantage for dairy producers, allowing them to include greater concentrations of this economical protein source with less risk for milk fat depression.

Research has shown positive results of lactation performance when RF-DDGS ( $\sim 6 \%$ fat) are included in the rations of lactating dairy cows (Mjoun et al., 2010; Castillo-Lopez et al., 2014; Ramirez-Ramirez et al., 2016). However, no publications describe animal performance and milk processing properties when cows consume RF-DDGS, and reports are mixed about the effect of feeding DG on cheese quality (Houck et al., 2007; Manimanna Sankarlal et al., 2015). Dairy scientists have implicated the inclusion of DDGS in the rations of lactating dairy cows as a cause of late blowing defects, primarily through introduction of spores (Houck et al., 2007). Our research group investigated the effects on the quality of baby Swiss cheese when feeding full-fat DDGS ( $\sim 13 \%$ fat) to dairy cows and observed no treatment effects in the quality of baby Swiss cheese when cows were fed up to $20 \%$ full-fat DDGS. Gas-forming spores were found in all TMR and all cheese samples regardless of treatment; however, spores were not found in any of the DDGS samples (Manimanna Sankarlal et al., 2015). Because decreasing the concentration of fat in DDGS can alleviate the risk of milk fat depression and because our previous research indicates that inclusion of DDGS in the diets of dairy cows does not cause late-blowing defects, we hypothesized that feeding RF-DDGS to lactating Holstein dairy cows supports milk production and composition with no further implications on quality of baby Swiss cheese. To further elucidate the effects of feeding DG on animal performance and milk processing properties, our objective was to feed RF-DDGS to lactating Holsteins and evaluate production responses, milk composition, and quality of cheese produced from that milk.

\section{MATERIALS AND METHODS}

\section{Animals and Diets}

All procedures were approved by the Iowa State University Animal Care and Use Committee. Thirty-six multiparous mid-lactation Holstein cows $(\mathrm{BW}=680$ $\pm 11 \mathrm{~kg} ; 106 \pm 27 \mathrm{DIM}$ ) were assigned randomly to 1 of 2 dietary treatment groups ( $\mathrm{n}=18$ per group) in a $2 \times 2$ crossover design and were housed in a 48-cow freestall pen equipped with Calan gates (American Calan, Northwood, NH). The freestalls were bedded with reclaimed manure solids. The daily cleaning routine included rake grooming of stalls by hand and manure scraping using a skid loader with a scraper attachment every time cows were moved out of the pen for milking. Each of the 2 experimental periods lasted $35 \mathrm{~d}$, with the first $14 \mathrm{~d}$ used as an acclimation or washout period to minimize carryover effects. Rations were formulated to meet or exceed nutrient requirements (NRC, 2001), to be isonitrogenous and isoenergetic (Tables 1 and 2), and to contain similar intestinally available AA concentrations based on the Cornell Net Protein and Carbohydrate System model with proprietary modifications (Purina Animal Nutrition LLC, Shoreview, MN). The control diet was a TMR based on corn, corn silage, and alfalfa hay supplemented with expeller soybean meal (SoyPlus, Landus Cooperative, Ames, IA) as a protein source. The RF-DDGS diet was formulated by using the same base ration as the control but with $20 \%$ of the DM being RF-DDGS (Poet Biorefining, Jewell, IA) containing approximately $6.0 \%$ fat in place of expeller soybean meal (Table 1). The RF-DDGS ration was supplemented with rumen-protected lysine (Kemin, Des Moines, IA) to make diets similar in available lysine (Table 1). Cows were housed together at the Iowa State University Dairy Farm (Ames, IA) in a 48-cow freestall pen and individually fed twice daily (0800 and 1600 h) through controlled-access gates (American Calan, Northwood, NH), allowing for approximately $10 \%$ refusals. Refusals were weighed and recorded daily. Feed ingredients in the TMR were mixed using a Patz V615 mixer (Patz Corp., Pound, WI). Cows were allowed ad libitum access to food and water except during their 3 daily milkings ( $8 \mathrm{~h}$ apart). Initially, cows were allowed 
Table 1. Formulations of control and reduced-fat dried distillers grains with solubles (RF-DDGS) rations

\begin{tabular}{lrc}
\hline & \multicolumn{2}{c}{ Treatment } \\
\cline { 2 - 3 } Ingredient, \% of DM & Control & 20\% RF-DDGS \\
\hline Corn silage & 33.7 & 30.3 \\
Alfalfa hay & 22.9 & 20.6 \\
Whole cotton seed & 7.9 & 7.1 \\
Ground corn & 14.4 & 15.1 \\
RF-DDGS & 0.0 & 19.5 \\
Expeller soybean meal $^{1}$ & 13.5 & 0.5 \\
Molasses $^{2}$ & 3.8 & 3.4 \\
Lysine $^{3}$ & 0.0 & 0.1 \\
Vitamin and mineral premix $^{2}$ & 3.8 & 3.4
\end{tabular}

${ }^{1}$ SoyPlus, Dairy Nutrition Plus (Des Moines, IA).

${ }^{2}$ Quality Liquid Feeds (Dunlap, IA). Custom vitamin and mineral supplement.

${ }^{3}$ USA lysine, Kemin Industries (Des Moines, IA).

to adapt to using the Calan gates before the start of the acclimation period. Additionally, individual milk production was recorded daily using a Boumatic milking system (Boumatic LLC, Madison, WI).

\section{Sample Collection and Analyses}

Because the first $14 \mathrm{~d}$ of each experimental period was an acclimation period, those data were excluded from analyses. Feed samples (TMR) were collected on d 21, 27, and 35 of each experimental period, and proximate analyses were done by an external laboratory (Dairylands Lab, Arcadia, WI). Fiber (acid detergent) was quantified by AOAC International (2016) official method 973.18, lignin was determined by AOAC International (2016) method 973.18, ether extract was determined using AOAC International (2016) method 945.16 and AOAC International (2016) method 920.39, feed fatty acids were quantified using the method described by Sukhija and Palmquist (1988), nitrogen was quantified using AOAC International (2016) method 990.0 , minerals were determined by inductively coupled plasma MS using AOAC International (2016) method 985.0 and AOAC International (2016) method 2011.14, NDF was determined as described by Mertens (2002), acid detergent insoluble $\mathrm{CP}$ was determined using AOAC International (2016) method 973.18 and AOAC International (2016) method 990.03, ash was determined by AOAC International (2016) method 942.05, and DM was determined using National Forage Testing Association method 2.1.4 (Shreve et al., 2006). After the 14-d acclimation period, individual milk samples were collected weekly from all 3 milkings. Individual milk samples [3 from each test day (d 21, 28, and 35); 108 samples] were sent for proximate analyses and assay of MUN and SCC to an external laboratory (Dairy Lab

Table 2. Analysis of control and reduced-fat dried distillers grains with solubles (RF-DDGS) rations ( $\mathrm{n}=6$ per treatment)

\begin{tabular}{|c|c|c|c|}
\hline \multirow[b]{2}{*}{ Item, $\%$ of DM unless noted } & \multicolumn{3}{|c|}{ Treatment } \\
\hline & RF-DDGS & Control & $20 \%$ RF-DDGS \\
\hline Moisture, \% & 8.09 & 43.10 & 40.83 \\
\hline DM, \% & 91.91 & 56.90 & 59.17 \\
\hline $\mathrm{CP}$ & 30.70 & 18.09 & 17.86 \\
\hline $\mathrm{ADF}$ & - & 21.37 & 20.52 \\
\hline NDF & 26.05 & 28.78 & 29.35 \\
\hline Lignin & - & 4.01 & 4.01 \\
\hline $\mathrm{ADICP}^{1}$ & - & 0.93 & 1.02 \\
\hline $\mathrm{NDICP}^{2}$ & - & 2.90 & 2.90 \\
\hline Fat & 5.67 & 4.80 & 5.21 \\
\hline Ash & 6.44 & 8.60 & 8.20 \\
\hline Calcium & 0.07 & 1.16 & 0.94 \\
\hline Phosphorus & 1.23 & 0.34 & 0.44 \\
\hline Magnesium & 0.30 & 0.26 & 0.24 \\
\hline Potassium & 1.43 & 1.96 & 1.81 \\
\hline Sulfur & 0.88 & 0.25 & 0.36 \\
\hline Sodium & 0.16 & 0.56 & 0.51 \\
\hline Chloride & 0.24 & 0.63 & 0.63 \\
\hline Metabolizable lysine, $^{3} \%$ of MP & & 7.16 & 7.13 \\
\hline Metabolizable methionine, ${ }^{3} \%$ of MP & & 2.19 & 2.19 \\
\hline $\mathrm{DCAD}, \mathrm{mEq} / 100 \mathrm{~g}$ & - & 40.81 & 27.89 \\
\hline $\mathrm{NE}_{\mathrm{L}},{ }^{4} \mathrm{Mcal} / \mathrm{kg}$ & - & 1.64 & 1.65 \\
\hline
\end{tabular}


Services, Dubuque, IA). Milk samples were analyzed individually, but results for each cow were composited to provide the mean composition of milk from each cow on each test day.

Blood samples were collected on d 29 to 31 of each period by jugular venipuncture and placed into lithium heparinized evacuated containers for nonesterified fatty acid (NEFA) quantification and into fluoridated vacutainers for blood glucose analysis (Becton Dickinson Co., Franklin Lakes, NJ). Blood glucose was assayed following the manufacturer's protocols (Wako Autokit Glucose, Wako Diagnostics, Richmond, VA). Blood NEFA were quantified following the manufacturer's protocol (Wako HR Series NEFA-HR, Wako Diagnostics). Subsamples of rumen fluid were collected via esophageal tube as described by Shen et al. (2012) approximately $4 \mathrm{~h}$ postfeeding to accommodate the milking schedule of the cows and for collection to take place at approximately maximal VFA production (Bryant, 1964). The first $200 \mathrm{~mL}$ of rumen fluid was discarded to limit saliva contamination. The next volume of rumen fluid was strained through 4 layers of cheesecloth, $\mathrm{pH}$ was measured immediately, and the rumen fluid was then frozen at $-20^{\circ} \mathrm{C}$. For analysis of VFA, subsamples of rumen fluid were thawed and acidified, and internal standards were added for subsequent analysis using a Varian 3900 gas chromatograph (Varian Inc., Palo Alto, CA) equipped with a DB-FFAP column $(30 \mathrm{~m} \times$ $0.25 \mathrm{~mm}$ i.d.; Agilent Technologies, Santa Clara, CA) as described by Drewnoski et al. (2014).

\section{Cheese Making}

During each of the two 35-d periods, on 3 to $4 \mathrm{~d}$ between d 24 and 34 (dictated by class schedule and weekend availability of personnel), milk from 1 complete milking (collected at $\sim 0630 \mathrm{~h}$ ) from all cows in each treatment group (control diet or RF-DDGS diet) was collected for cheese making $(\mathrm{n}=14$ cheeses in total; $\mathrm{n}$ $=7$ cheeses per group). It is possible that some variability in milk composition occurred during this $10-\mathrm{d}$ window, but because the milk was pooled, individual cow variation should be minimal. The milk cans and dump buckets were washed with automatically diluted detergents (Ecolab Oasis Enforce, St. Paul, MN) and sanitized with automatically diluted food-grade iodinebased sanitizer (Ecolab Mikroklene, St. Paul, MN). Teats were sanitized with $300 \mathrm{ppm}(300 \mathrm{mg} / \mathrm{L})$ Chlorine predip (EcaLogic, Zurex Corp., Middleton, WI) and a $1 \%$ iodine, $5 \%$ emollient postmilking teat dip (FS-103, Morgan-Gallacher Inc., Santa Fe Springs, CA) and wiped dry with individual towels before collecting milk from each cow. Milk from 2 groups of 6 cows was collected by rerouting the milk line into a clean dump bucket. After the milk of 2 cows fed the same diet filled a dump bucket, it was dumped through cheesecloth into a labeled milk can. Milk was transported at ambient temperature to the Iowa State University Center for Crops Utilization Research pilot plant in the Food Sciences Building at Iowa State University within 20 min of collection of milk from the last cow. The milk cans were immediately weighed and milk was tested within 60 min of collection for fat, protein, and lactose concentration using an automatic analyzer (LactiCheck milk mini analyzer, Page and Pederson Inc., Hopkinton, MA) before further processing. Individuals who collected milk at the dairy farm showered and changed into clean clothes before participating in cheese making to minimize additional external contamination of milk to be used for cheese production.

If the fat:protein ratio was not $0.88 \pm 0.05$, the milk was separated and standardized; cream or skim from the milk collected from the same experimental cows was added to raise or lower the ratio to $0.88 \pm 0.05$, respectively. Milk was separated by using a Type LWA 205 Westfalia separator at $219 \mathrm{rpm}$ in 2.5 dial setting (Dusseldorf, Germany). Approximately $68 \mathrm{~kg}$ of standardized milk from each dietary treatment was poured into a labeled cheese vat and heat treated $\left(63^{\circ} \mathrm{C}\right.$ for 2 min to decrease the initial load of bacteria) by delivering steam-heated water to the jacketed vat while the milk was gently agitated. After heat treatment, the milk was gradually cooled to $33^{\circ} \mathrm{C}$ by running cold water in the jacketed vat while the milk was gently agitated.

Baby Swiss-style cheese was made by adding $0.32 \pm$ $0.03 \mathrm{~g}$ of Choozit TA 60 (Streptococcus salivarius ssp. thermophilus, DuPont Danisco, New Century, KS) and $0.12 \pm 0.02 \mathrm{~g}$ of Choozit eyes (Propionibacterium freudenreichii ssp. shermanii, DuPont Danisco)/100 kg of $33^{\circ} \mathrm{C}$ milk. Microbial coagulant $(13 \mathrm{~mL} / 100 \mathrm{~kg}$ of milk, DCI Supreme, Dairy Connection Inc., Madison, WI) was diluted with cold water to a ratio of 1:40 and added with slow agitation for $1 \mathrm{~min}$ after $30 \mathrm{~min}$ of ripening. The cheese curd was allowed to set for approximately 30 min, tested for firmness manually and visually, and manually cut with $12-\mathrm{cm}$ wire curd knives. After a 5-min heal, the 35-min forework period of intermittent gentle stirring occurred. About $25 \%$ of the vat volume of whey was removed (predraw), followed by constant stirring and addition of water (3-5\% of the vat volume) at $33^{\circ} \mathrm{C}$. Gradually, the curds were cooked by increasing the temperature to $40^{\circ} \mathrm{C}$ over a 15 -min period and then to $46^{\circ} \mathrm{C}$ over a 10 -min period by adding steam to the jacket of the vat, with continuous curd stirring. Warm water $\left(\sim 10 \%\right.$ of the vat volume) was added at $44^{\circ} \mathrm{C}$ to facilitate the increase in temperature of the cheese 
to $46 \pm 1^{\circ} \mathrm{C}$, at which point the curds were held for 42 min (postwork). Whey was removed after postwork at a target $\mathrm{pH}$ of 6.4 .

Pressing began approximately $4 \mathrm{~h}$ from the time culture was added to the milk. Cheese curds were collected into perforated stainless steel Longhorn hoops and pressed in the whey using a $7-\mathrm{kg}$ weight $(0.02 \mathrm{~kg} /$ $\mathrm{cm}^{2}$ ) on each hoop follower for $15 \mathrm{~min}$. The whey was drained completely and the cheese block was pressed for $1 \mathrm{~h}$ with $11 \mathrm{~kg}\left(0.04 \mathrm{~kg} / \mathrm{cm}^{2}\right), 1 \mathrm{~h}$ with $23 \mathrm{~kg}(0.07$ $\left.\mathrm{kg} / \mathrm{cm}^{2}\right)$, and $3 \mathrm{~h}$ with $35 \mathrm{~kg}\left(0.11 \mathrm{~kg} / \mathrm{cm}^{2}\right)$. The weights were removed and cheese was ripened in an empty basin for an additional 5 to $8 \mathrm{~h}$ at $22 \pm 3^{\circ} \mathrm{C}$. The ripening time was based on the time required for the $\mathrm{pH}$ of the cheese to decrease to $5.25 \pm 0.05$ (Accumet Basic AB15, Fisher Scientific Inc., Pittsburgh, PA). According to Kosikowski and Mistry (1997), the optimal pH at the time of salting for Swiss-style cheeses is between 5.2 and 5.4. Cheese rounds were removed from the hoops, cut in half, and placed in saturated brine containing $23 \% \mathrm{NaCl}$ and $0.38 \% \mathrm{CaCl}_{2}$ for up to $9 \mathrm{~h}$ depending on block weight, which averaged $5.3 \mathrm{~kg}(\sim 30 \mathrm{~min} / \mathrm{kg}$ of cheese).

Cheese surfaces were allowed to dry for $1 \mathrm{~h}$ before rounds were vacuum packed in clear 3-mil vacuum-seal bags $(30.5 \times 40.5 \mathrm{~cm}$; UltraSource LLC, Kansas City, MO) with a Koch vacuum packing machine (Koch Equipment LLC, Kansas City, MO). Cheeses were stored at $10 \pm 1^{\circ} \mathrm{C}$ for $7 \mathrm{~d}$ (precool), $22 \pm 3^{\circ} \mathrm{C}$ for $21 \mathrm{~d}$ (warm room), and $4 \pm 1^{\circ} \mathrm{C}$ for $60 \mathrm{~d}$ (cold room; Kosikowski and Mistry, 1997). Cheeses were flipped weekly.

\section{Cheese Analyses}

Proximate analysis was conducted using standard methodology at South Dakota State University (Dairy and Food Science Department, Brookings, SD). Fat was analyzed by the Mojonnier method (Atherton and Newlander, 1977), moisture content using a forced-draft oven (model OV-490A-2; Blue M, Blue Island, IL), chloride using a Corning chloride analyzer (Ciba Corning Diagnostics, Medfield, MA) based on the Volhard test (Marshall, 1992), and total protein by measuring total nitrogen in the cheeses using the Kjeldahl method (Kjeltec 2200 Auto Distillation Unit, Foss, Eden Prairie, $\mathrm{MN})$.

\section{Sensory Analyses}

Sensory quality evaluation began after $62 \pm 6 \mathrm{~d}$ of aging. A descriptive sensory analysis panel, comprising
6 trained panelists, evaluated the quality of the cheeses. Procedures for use of human subjects in research were approved by the Iowa State University Institutional Review Board. Training consisted of at least $5 \mathrm{~h}$ of initial training followed by $1 \mathrm{~h}$ of refresher training between the first and second official tasting periods (separated by a month). The expectations for "ideal" characteristics of Swiss and baby Swiss cheese were explained to panelists (Cakir and Clark, 2009). For the appearance attributes, photographs of ideal Swiss and baby Swiss cheeses as well as those exhibiting varying degrees of specific defects were used to assist with initial training. To instill specific appearance, aroma, flavor, and body and texture defects in the minds of the panelists, products exhibiting varying levels of defects were used, which served as references on a 15-cm unstructured line scale during training sessions. The facilitator and panelists created a "cheat sheet" to augment training and tasting sessions. The descriptors and references were anchored on the $15-\mathrm{cm}$ unstructured line scale to remind panelists of intensity references. Additionally, to assist with eye size evaluation, panelists were provided a plastic square with a standard hole punched in it to indicate ideal (small) eyes and a penny to indicate large eyes.

To representatively sample cheeses for evaluation by panelists, every cheese was systematically cut by hand with a sanitized butcher knife on a sanitized cutting board into at least 20 pieces of approximately $1-\mathrm{cm}$ thickness. The cutter began by making a $1-\mathrm{cm}$ slice at the outside round of the cheese and proceeded to make subsequent slices around the round, gradually forming a smaller and smaller square out of the cheese (Figure 1). Slices were laid out sequentially on sanitized, dry trays for photographing (Figures 2, 3, 4, and 5). When the cheese piece was almost square, the piece of cheese was flipped vertically and the remaining pieces were cut, resulting in 3 to 4 horizontal slices representing the top and bottom "faces" and 1 to 2 innermost slices. Based on their sequential placement on trays, cheese slices were selected randomly for bagging and presentation to panelists using a random number generator. A plastic index card-sized template $(8.5 \mathrm{~cm} \times 5 \mathrm{~cm} \times 1 \mathrm{~cm})$ was placed on each randomly selected master slice to make a consistent principal display for panelist evaluation. Selected slices were placed into individual resealable snack bags, labeled with random 3-digit codes corresponding to the original cheese from which they were cut, and stored at $4^{\circ} \mathrm{C}$ until the sensory panel.

During actual cheese sensory evaluation sessions, panelists were provided 1 blank score sheet per sample, which was the same as the cheat sheet minus the anchored reference words. Panelists were trained to iden- 


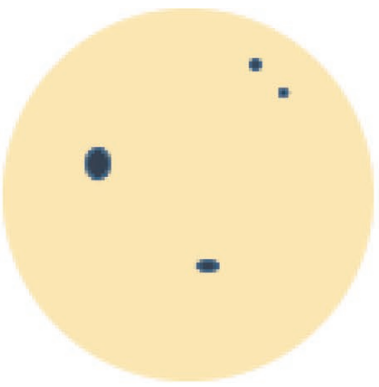

Original cheese round

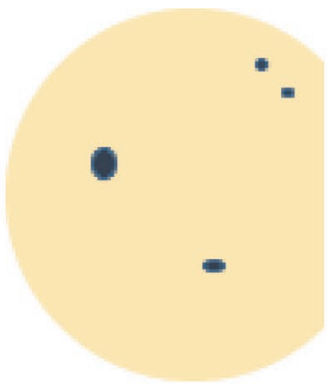

One slice removed

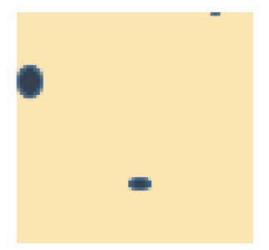

Eight slices removed

\section{Sixteen slices removed}

Figure 1. Visual representation of the process used to systematically slice cheeses for photographs and evaluation by trained panelists. Color version available online.

tify appearance, aroma, flavor, and body and texture attributes, but trigger words on the cheat sheets served to remind them where on the score sheet to mark the intensity of each cheese attribute on the 15 -cm line scale. While in individual booths, panelists were provided individual bagged samples; a plastic knife for cutting cheese for body, texture, and taste evaluation; and water and green grapes for cleansing the palate. Panelists were instructed to first evaluate visual attributes only on the principal display presented to them in the bag. Panelists then evaluated cheese body and texture followed by aroma and flavor.

\section{Statistical Analyses}

Milk components, yield, and animal performance metrics were analyzed as a $2 \times 2$ crossover design. The first $14 \mathrm{~d}$ of the experiment were considered an adaptation phase to the diet, and data from this 2 -wk period

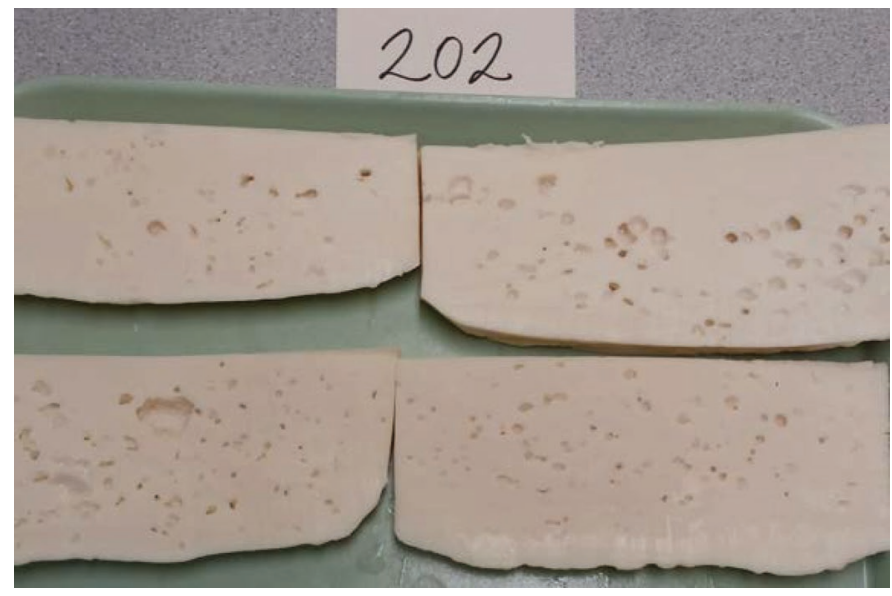

Figure 2. Representative photograph of a tray of sliced baby Swiss cheese from milk of cows fed the control diet in period 1. Color version available online. were not used in the statistical analyses. The same scheme was followed once cows switched diets during the second period to alleviate any potential carryover effects and allow enough time to dissipate any residual effect of the preceding dietary treatment. Data were analyzed using the MIXED procedure of SAS version 9.4 (SAS Institute Inc., Cary, NC). The model included the fixed effects of treatment, treatment sequence, and period and the random effect of cow nested within group. Means with significant treatment effects were separated using LSMEANS with the PDIFF option. Feed fatty acids and feed proximate analysis results were analyzed using the MIXED procedure of SAS with the fixed effect of treatment. Sensory attributes of cheese were analyzed using the MIXED procedure of SAS, with the model including the fixed effect of treatment. Means were separated using LSMEANS with the PDIFF option. Differences were considered significant when $P<0.05$.

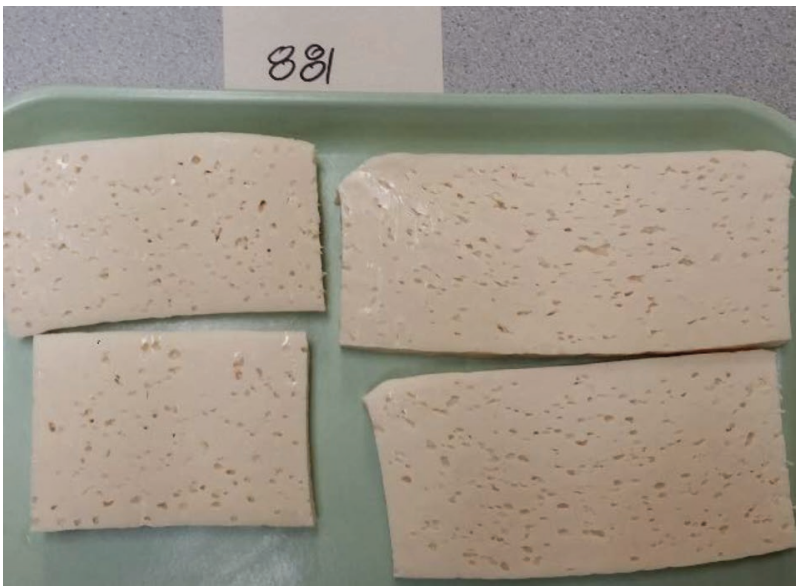

Figure 3. Representative photograph of a tray of sliced baby Swiss cheese from milk of cows fed the reduced-fat dried distillers gains with solubles diet in period 1. Color version available online. 


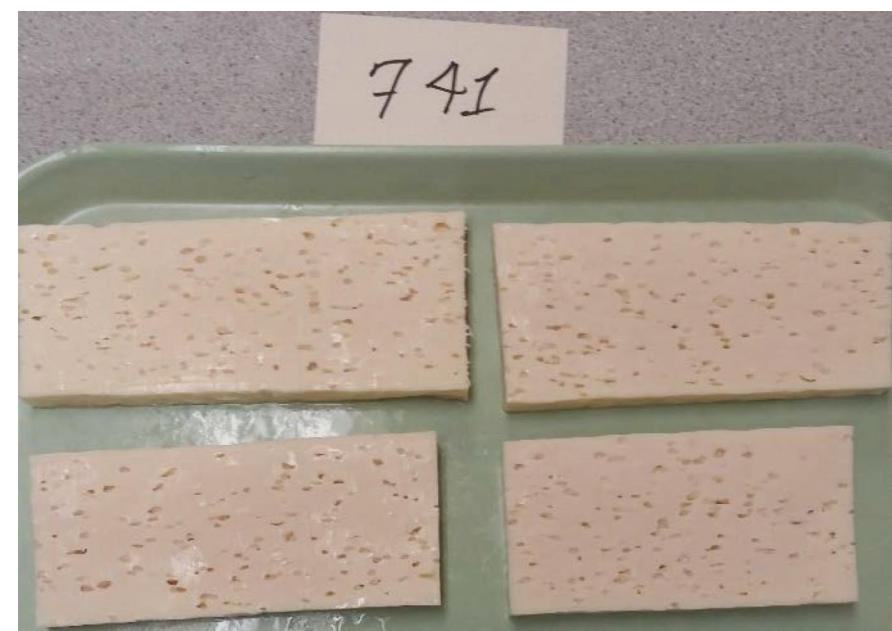

Figure 4. Representative photograph of a tray of sliced baby Swiss cheese from milk of cows fed the control diet in period 2. Color version available online.

\section{RESULTS AND DISCUSSION}

As designed, diets were isoenergetic and isonitrogenous (Table 2) as evidenced by the similar $\mathrm{NE}_{\mathrm{L}}$ and CP. Differences in sodium, potassium, sulfur, and calcium resulted in a significantly lower DCAD in RFDDGS rations (Table 2). Feed fatty acid compositions are reported in Table 3. As expected, the RF-DDGS diet contained slightly greater concentrations of total UFA because corn oil contains 92\% UFA (Ramos et al., 2009).

Dry matter intake was greater for cows fed RF-DDGS; however, milk, FCM, and ECM yields (Table 4) were unaffected. These results are consistent with results of Paz and Kononoff (2014) and Ramirez-Ramirez et al. (2016) regarding feeding RF-DDGS and effects on milk composition where increased DMI was observed for cows fed RF-DDGS. Additionally, milk fat percentage (consistent with Ramirez-Ramirez et al., 2016), total milk fat production, total milk protein production, lactose percentage, and total lactose production were unaffected by treatment, which is consistent with results of Mjoun et al. (2010) and Paz and Kononoff (2014). Previous studies have indicated that increased DCAD values can increase milk fat percentage (Hu et al., 2007; Wildman et al., 2007; Harrison et al., 2012); this result, however, was not seen in our study (Table 4), which is consistent with results reported by Erdman et al. (2011). No differences were observed in composition of milk from cows fed either diet with the exception of milk protein percentage, which increased for cows fed RF-DDGS lysine without a concomitant change in total milk protein production. The supplementary lysine in the RF-DDGS likely does not explain this effect

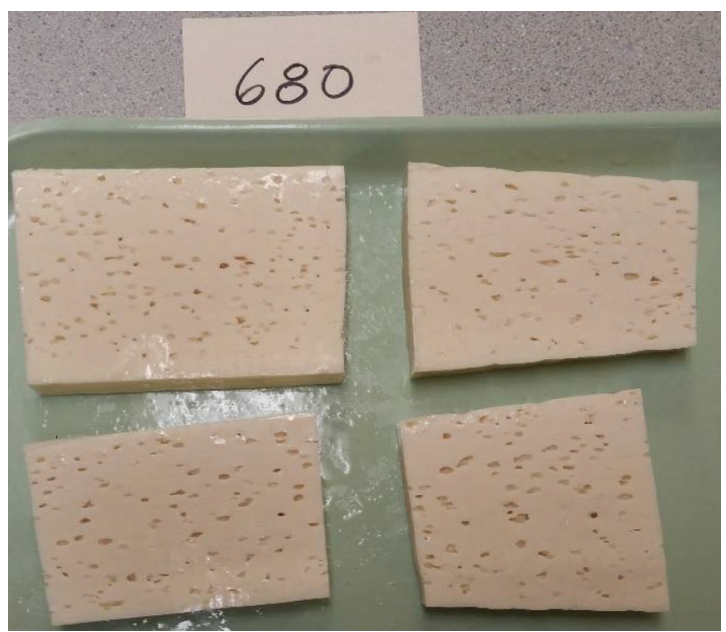

Figure 5. Representative photograph of a tray of sliced baby Swiss cheese from milk of cows fed the reduced-fat dried distillers gains with solubles diet in period 2. Color version available online.

because the diets were formulated to provide similar metabolizable lysine (Table 1). Although further work would be needed to fully elucidate this response in our experiment, taken together, a decrease in MUN and increased milk protein percentage for cows fed RF-DDGS may indicate improved nitrogen metabolism via greater nitrogen digestibility (Ramirez-Ramirez et al., 2016) or improvement in efficiency of nitrogen utilization in the gut or mammary gland (Mjoun et al., 2010; Paz and Kononoff, 2014). These results are consistent with

Table 3. Feed fatty acid composition (\% by weight)

\begin{tabular}{lrccc}
\hline & \multicolumn{2}{c}{ Treatment } & & \\
\cline { 2 - 3 } Fatty acid & Control & RF-DDGS & & \\
& & SEM & $P$-value \\
\hline C12:0, C14:0 & 0.30 & 0.23 & 0.09 & 0.61 \\
C14:1 & 0.00 & 0.00 & NA $^{2}$ & NA \\
C16:0 & 20.27 & 19.20 & 0.30 & 0.03 \\
C16:1 & 0.37 & 0.28 & 0.02 & 0.01 \\
C17:0 & 0.00 & 0.00 & NA & NA \\
C18:0 & 3.22 & 2.68 & 0.08 & $<0.01$ \\
C18:1 & 18.68 & 20.55 & 0.21 & $<0.01$ \\
C18:2 & 50.02 & 51.43 & 0.27 & $<0.05$ \\
C18:3 & 5.71 & 4.21 & 0.15 & $<0.01$ \\
C19:0, C20:0 & 0.58 & 0.60 & 0.01 & 0.22 \\
C20:1 & 0.27 & 0.30 & 0.01 & 0.01 \\
C20:2, C20:3 & 0.00 & 0.00 & NA & NA \\
C20:4 & 0.00 & 0.00 & NA & NA \\
C22:1 & 0.00 & 0.00 & NA & NA \\
C22:6 & 0.00 & 0.00 & NA & NA \\
C24:0 & 0.00 & 0.00 & NA & NA \\
C24:1 & 0.00 & 0.00 & NA & NA \\
Total UFA & 75.04 & 76.77 & 0.32 & $<0.05$ \\
MUFA & 19.31 & 21.14 & 0.20 & $<0.01$ \\
PUFA & 55.73 & 55.63 & 0.25 & 0.80 \\
\hline
\end{tabular}

${ }^{1}$ Reduced-fat dried distillers grains with solubles.

${ }^{2}$ Not applicable. 
those of Castillo-Lopez et al. (2014), who reported that feeding cows RF-DDGS had no effect on milk yield and tended to increase milk protein percentage. Additionally, Ramirez-Ramirez et al. (2016) observed that cows fed RF-DDGS produced milk with greater protein percentage and no effect on milk fat percentage, which is consistent with our study. However, they observed increased milk yield for those cows fed either DDGS or RF-DDGS, which was not seen in this study; this may be explained by the difference in DMI observed in each study. In this study, cows consumed $1.29 \mathrm{~kg}$ more DM compared with our control, whereas Ramirez-Ramirez et al. (2016) reported $4.4 \mathrm{~kg}$ more DMI for cows fed RF-DDGS than cows on the control diet. In the present study, milk protein percentage was significantly increased and MUN was decreased when cows were fed RF-DDGS, suggesting that protein utilization may be improved when cows are fed RF-DDGS when supplemented diets contain similar AA profiles, which has been reported by Mjoun et al. (2010). However, because protein utilization was not a primary goal of the study and because lysine concentration was not determined chemically, further studies would need to be done to confirm this observation. Because of the increased DMI of cows fed RF-DDGS, all metrics of feed efficiency (Table 4) were decreased relative to the control. This response is not consistent with prior research that reported no change in feed efficiency when early-lactation cows were fed RF-DDGS in place of a soy-based protein (Mjoun et al., 2010). A plausible explanation for this discrepancy is that our cows were in mid lactation and likely in positive energy balance, which allowed cows to partition additional energy toward body reserves. In line with this, our data indicate that cows consuming RF-DDGS tended to gain $5 \mathrm{~kg}$ more compared with cows on the control diet.

No difference in rumen $\mathrm{pH}$ was observed, which is consistent with results from trials with similar diets reported by Castillo-Lopez et al. (2014). Furthermore, acetate:propionate ratios were decreased and valerate concentration was increased (Table 5), which is consistent with the results of Ramirez-Ramirez et al. (2016), who fed similar diets. In contrast to the results related to NEFA concentrations of Mjoun et al. (2010), we saw no difference in NEFA concentration, which is likely because the cows used in that study were in early lactation, whereas ours were in mid lactation. Finally, consistent with Mjoun et al. (2010), blood glucose concentrations were not different between treatments. Combined, our results are a confirmation of prior research that reports the effectiveness of including RF-DDGS in the rations of lactating dairy cows (Mjoun et al., 2010; CastilloLopez et al., 2014; Ramirez-Ramirez et al., 2016). Furthermore, these results demonstrate that currently commercially available RF-DDGS result in increased DMI but can be fed at a 20\% (DM basis) inclusion rate without negatively influencing milk composition. The increased DMI for cows fed RF-DDGS may be acceptable if the economics of feeding RF-DDGS in place of a soy-based protein are favorable.

Table 4. Effects of feeding reduced-fat dried distillers grains with solubles (RF-DDGS) to lactating Holstein dairy cows on milk components and yield

\begin{tabular}{|c|c|c|c|c|}
\hline \multirow[b]{2}{*}{ Item } & \multicolumn{2}{|c|}{ Treatment } & \multirow[b]{2}{*}{ SEM } & \multirow[b]{2}{*}{$P$-value } \\
\hline & Control & RF-DDGS & & \\
\hline $\mathrm{DMI}, \mathrm{kg} / \mathrm{d}$ & 25.96 & 27.25 & 0.69 & $<0.01$ \\
\hline Nitrogen intake, $\mathrm{kg} / \mathrm{d}$ & 4.70 & 4.87 & 0.12 & $<0.01$ \\
\hline $\mathrm{NE}_{\mathrm{L}}$ intake, Mcal/d & 42.83 & 44.96 & 1.14 & $<0.01$ \\
\hline Milk yield, $\mathrm{kg} / \mathrm{d}$ & 35.66 & 35.39 & 0.98 & 0.33 \\
\hline $\mathrm{FCM}^{1}$ & 36.27 & 35.78 & 0.89 & 0.11 \\
\hline $\mathrm{ECM}^{2}$ & 36.43 & 36.30 & 0.89 & 0.66 \\
\hline Milk fat, kg/d & 1.27 & 1.25 & 0.04 & 0.42 \\
\hline Milk fat, $\%$ & 3.65 & 3.61 & 0.10 & 0.52 \\
\hline Milk protein, $\mathrm{kg} / \mathrm{d}$ & 1.05 & 1.08 & 0.03 & 0.20 \\
\hline Milk protein, $\%$ & 3.01 & 3.11 & 0.05 & $<0.05$ \\
\hline Lactose, $\mathrm{kg} / \mathrm{d}$ & 1.63 & 1.62 & 0.06 & 0.88 \\
\hline Lactose, $\%$ & 4.62 & 4.64 & 0.05 & 0.82 \\
\hline Milk TS, \% & 12.19 & 12.28 & 0.17 & 0.48 \\
\hline MUN, mg/dL & 14.18 & 12.99 & 0.29 & $<0.01$ \\
\hline $\mathrm{SCC}$, cells $/ \mathrm{mL} \times 1,000$ & 232.57 & 287.22 & 168.84 & 0.72 \\
\hline BW change, $\mathrm{kg}$ & +12.19 & +17.33 & 2.43 & 0.14 \\
\hline Feed efficiency, $\mathrm{kg}$ of milk/kg of DMI & 1.42 & 1.34 & 0.05 & $<0.01$ \\
\hline FCM efficiency, $\mathrm{kg}$ of $\mathrm{FCM} / \mathrm{kg}$ of DMI & 1.44 & 1.36 & 0.04 & $<0.01$ \\
\hline ECM efficiency, $\mathrm{kg}$ of ECM $/ \mathrm{kg}$ of DMI & 1.45 & 1.38 & 0.04 & $<0.01$ \\
\hline
\end{tabular}


Table 5. Effects of feeding reduced-fat dried distillers grains with solubles (RF-DDGS) to dairy cows on BW, blood components, rumen fluid $\mathrm{pH}$, and ruminal short-chain fatty acid concentrations

\begin{tabular}{|c|c|c|c|c|}
\hline \multirow[b]{2}{*}{ Item } & \multicolumn{2}{|c|}{ Treatment } & \multirow[b]{2}{*}{ SEM } & \multirow[b]{2}{*}{$P$-value } \\
\hline & Control & RF-DDGS & & \\
\hline Rumen fluid pH & 6.55 & 6.50 & 0.06 & 0.37 \\
\hline Blood NEFA, ${ }^{1} \mu \mathrm{Eq} / \mathrm{L}$ & 164.54 & 159.53 & 6.10 & 0.51 \\
\hline Blood glucose, $\mathrm{mg} / \mathrm{dL}$ & 53.08 & 54.85 & 1.24 & 0.32 \\
\hline \multicolumn{5}{|c|}{ Short-chain fatty acids, \% } \\
\hline Acetate & 63.70 & 61.15 & 0.57 & $<0.01$ \\
\hline Butyrate & 10.99 & 11.35 & 0.25 & 0.33 \\
\hline Isobutyrate & 0.60 & 0.60 & 0.04 & 0.98 \\
\hline Isovalerate & 2.66 & 2.28 & 0.10 & 0.01 \\
\hline Propionate & 20.67 & 23.03 & 0.60 & $<0.01$ \\
\hline Valerate & 1.39 & 1.59 & 0.03 & $<0.01$ \\
\hline Acetate:propionate & 3.16 & 2.75 & 0.10 & $<0.001$ \\
\hline
\end{tabular}

${ }^{1} \mathrm{NEFA}=$ nonesterified fatty acids.

Swiss cheese and baby Swiss cheese standards for quality evaluation in the present study were based on Cakir and Clark (2009). Baby Swiss cheese eyes should be glossy, completely round, from 0.3 to $0.8 \mathrm{~cm}$ in diameter, and evenly distributed throughout the body of the cheese. The cheese should have a mild nutty (roasted hazelnut) and propionic acid aroma and flavor character with little to no apparent sour or lactic acid taste. The body of baby Swiss should be firm as indicated by being somewhat resistant to initial compression between the thumb, forefinger, and middle finger, but should break apart between fingers without crumbling or seeming too rubbery or dry (corky). Upon mastication, the texture should be smooth rather than grainy or rough. Other than a slight bitter aftertaste, baby Swiss cheese should "clean up," leaving no fruity, fermented, rancid, yeasty, or other foreign flavors on the palate (Cakir and Clark, 2009).
Regarding flavor and body and texture attributes of baby Swiss cheese, "ideal" or "typical" mean scores for the attributes of importance would be close to zero for acid, flat, unclean, mealy/grainy, pasty, and weak; the ideal mean score for bitter would be up to 5 and for curdy would be close to 7.5 (Table 6). Mean scores for RF-DDGS and control cheeses were close to the ideal, and not significantly different, for all attributes (Table 7).

The visual appearance of Swiss-type cheeses is very important, and producing cheeses with a typical number, size, and distribution of eyes is difficult (Guggisberg et al., 2015). In the case of the present work, ideal mean scores for the attributes of importance would be close to zero for eye distribution, eye shape, and gas formation (defects) and close to the midpoint on the 15-cm line scale (7.5) for eye amount, gloss, and size. The baby Swiss cheeses from the control and RF-DDGS treatments in the present study (Table 7; Figures 2-5) had glossy eyes (7.10 and 7.14, respectively) with slightly uneven distribution (3.65 and 3.33, respectively) and a propensity for irregular (somewhat flattened or oval) shape (8.39 and 8.19, respectively). In general, the cheeses looked more like Lorraine (Saputo) or lacey Swiss (Boar's Head) than baby Swiss because the small to very small eyes (5.92 and 5.19, respectively) were overset (7.74 and 7.83 , respectively). The RF-DDGS cheeses did not differ from control cheeses for any attribute except size of eyes (Table 7). Although mean scores for eye size of control cheeses were closer to ideal than those of the RF-DDGS cheeses $(P<0.05)$, the difference was not great enough to be practical or obvious to the average consumer. The overset appearance of all of the cheeses in the present study may be partially explained by the absence of Lactobacillus

Table 6. Descriptive analysis lexicon for baby Swiss cheeses (adapted from Cakir and Clark, 2009)

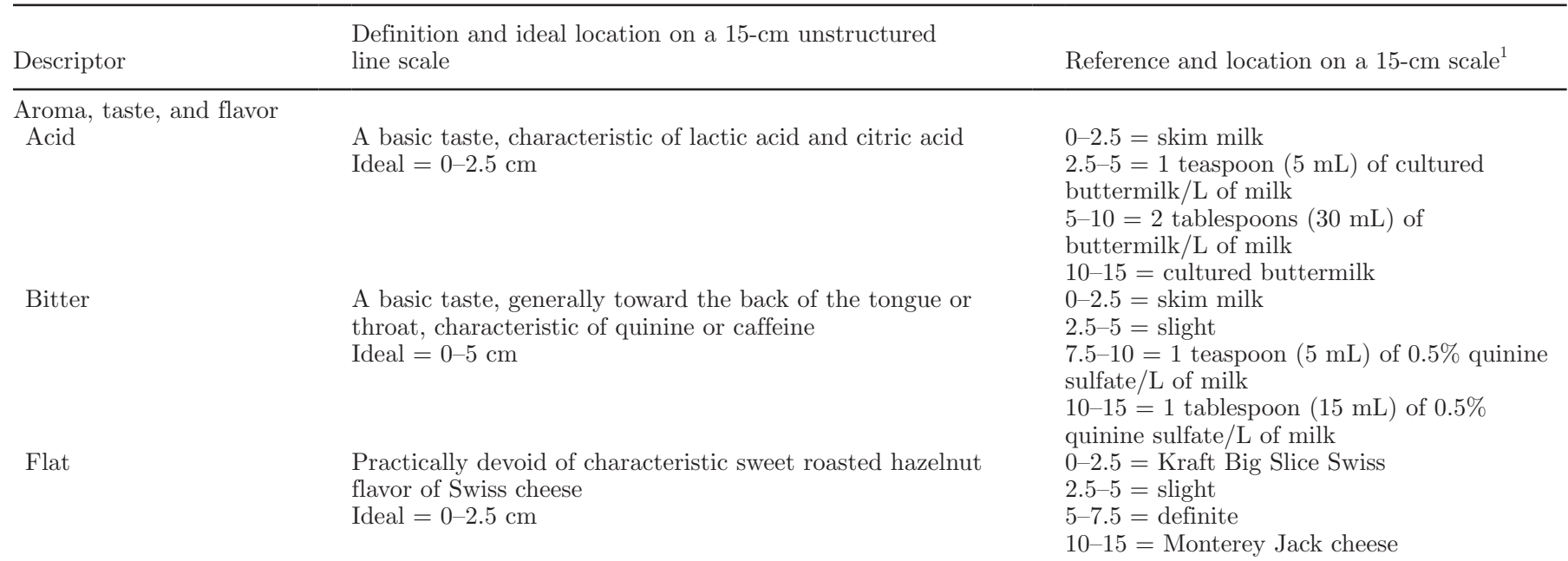


Table 6 (Continued). Descriptive analysis lexicon for baby Swiss cheeses (adapted from Cakir and Clark, 2009)

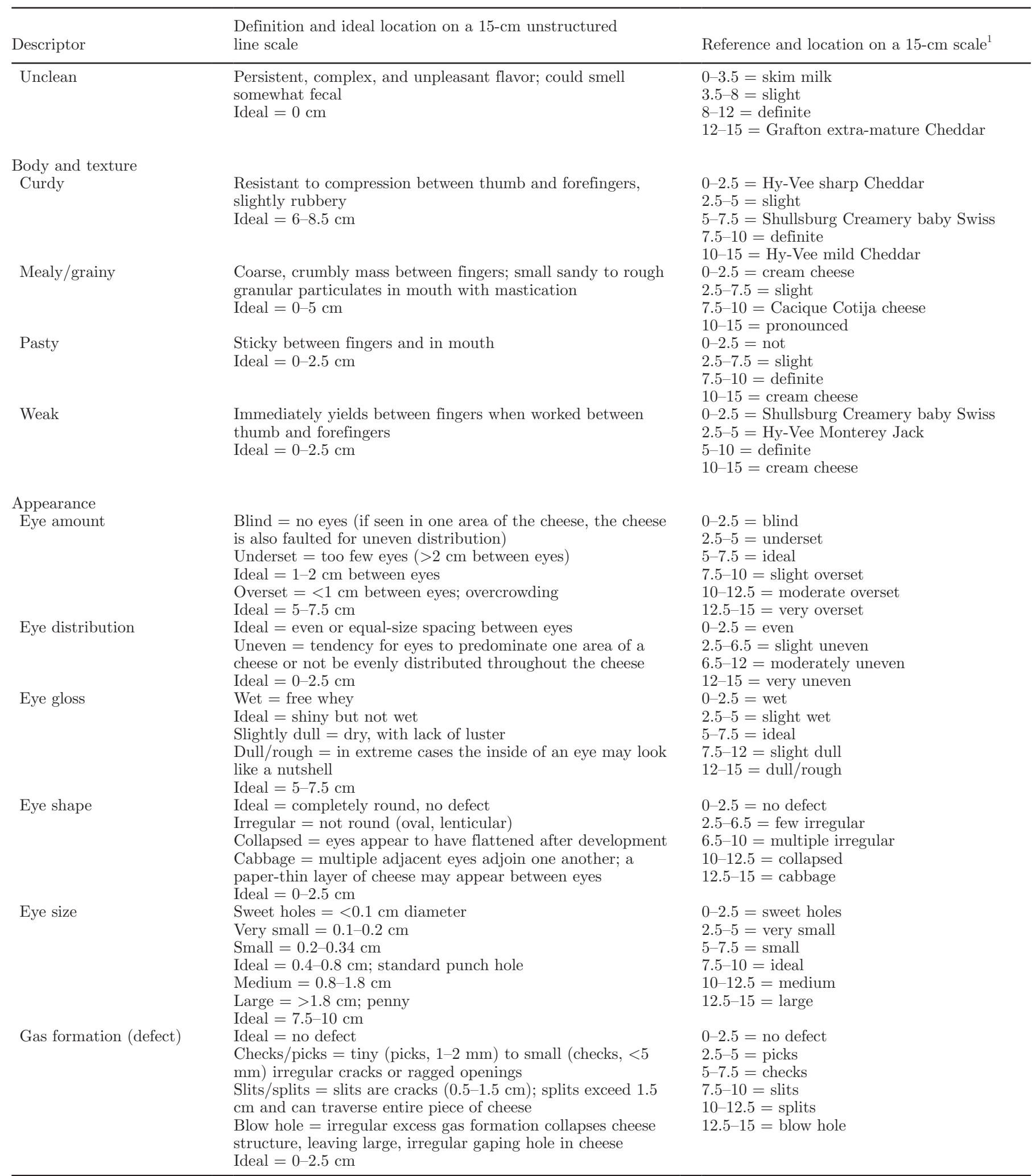

${ }^{1}$ Photographic images used for appearance references are not included in the present work. 
TESTROET ET AL.

Table 7. Mean scores ${ }^{1}$ for cheese flavor, body and texture, and appearance of eyes

\begin{tabular}{|c|c|c|c|c|}
\hline \multirow[b]{2}{*}{ Item } & \multicolumn{2}{|c|}{ Treatment } & \multirow[b]{2}{*}{ SEM } & \multirow[b]{2}{*}{$P$-value } \\
\hline & Control & RF-DDGS $^{2}$ & & \\
\hline \multicolumn{5}{|l|}{ Flavor } \\
\hline Acid & 0.99 & 1.07 & 0.14 & 0.68 \\
\hline Bitter & 3.74 & 3.48 & 0.34 & 0.56 \\
\hline Flat & 1.33 & 1.60 & 0.23 & 0.40 \\
\hline Unclean & 1.40 & 1.86 & 0.29 & 0.22 \\
\hline \multicolumn{5}{|l|}{ Body and texture } \\
\hline Curdy & 7.88 & 7.46 & 0.34 & 0.36 \\
\hline Mealy/grainy & 5.60 & 6.44 & 0.42 & 0.13 \\
\hline Pasty & 0.66 & 0.91 & 0.18 & 0.30 \\
\hline Weak & 0.89 & 1.13 & 0.16 & 0.25 \\
\hline \multicolumn{5}{|l|}{ Appearance of eyes } \\
\hline Amount & 7.74 & 7.83 & 0.31 & 0.83 \\
\hline Distribution & 3.65 & 3.33 & 0.40 & 0.56 \\
\hline Gloss & 7.10 & 7.14 & 0.22 & 0.88 \\
\hline Shape & 8.39 & 8.19 & 0.28 & 0.59 \\
\hline Size & 5.92 & 5.19 & 0.24 & 0.02 \\
\hline Gas formation (defects) & 3.82 & 4.69 & 0.59 & 0.27 \\
\hline
\end{tabular}

helveticus. O'Sullivan et al. (2016) reported on the effect of intentionally adding or not adding $L$. helveticus and Lactobacillus casei to a Swiss-type cheese. In the absence of L. helveticus, excess lactose, galactose, and citrate, available during the initial ripening stages, provided substrate to the facultative heterofermentative $L$. casei to produce excessive gas during ripening (overset). Although the presence of individual microorganisms was not enumerated in the present study and sanitation practices were attended to in order to minimize nonstarter bacteria contamination, the absence of $L$. helveticus in the present work may partially explain the overset cheeses, providing support for the work of O'Sullivan et al. (2016).

Written comments by trained panelists and enumeration of appearance defects on 3-digit coded trays of sliced cheeses (representative images included in Figures 2-5) support the results compiled in Table 7. When all slices were considered (in addition to the randomly selected samples presented to panelists), uneven eye distribution ( 84 and $63 \%$ of slices from control and RF-DDGS cheeses, respectively), irregular eye shape (76 and $68 \%$, respectively), and very small eyes (59 and $60 \%$, respectively) predominated slices. Blind areas (20 and $17 \%$, respectively), wet or whey (10 and $14 \%$, respectively), and cabbage defects (12 and $8 \%$, respectively) were occasionally seen. Collapsed eyes (20 and $44 \%$, respectively) and slits (18 and $28 \%$, respectively) appeared with higher frequency in RF-DDGS cheeses, but the more serious defect, blown, was more prevalent in control cheeses (33 and 13\% of slices, respectively). None of the cheeses were split. Late-fermentation defects, particularly splits and blown defects, have a negative effect on processors (i.e., slicing ability is affected negatively) and consumers (who expect round, glossy eyes); therefore, bad eyes are an economic issue (White et al., 2003; Manimanna Sankarlal et al., 2015). To limit late-fermentation defects in Swiss-type cheese, Fröhlich-Wyder et al. (2002) recommended propionibacteria strains of low aspartase activity, addition of L. casei strains, and omission of L. helveticus. To minimize splits, White et al. (2003) concluded that careful selection of $L$. helveticus and $P$. shermanii cultures is important, particularly if the cheese target moisture content is high (e.g., $>37 \%$ ). We did not inoculate with L. helveticus, and cheeses were ripened $78 \pm 5 \mathrm{~d}$ total, from brine to knife, before evaluation.

Distillers grains with solubles have been implicated in late-blowing defects in cheese in the past (Houck et al., 2007). Even though the Houck article was not published in a peer-reviewed journal, the article is read by farmers and processors, so the implications of the article are relevant. In our previous work, it was shown that DDGS did not contain spores, yet TMR, manure, milk, and cheese did contain gas-producing spores (Manimanna Sankarlal et al., 2015). The present work was undertaken in an environment known to harbor gas-forming spores to investigate whether cheese made from milk of cows fed RF-DDGS was more prone to defects than cheese made from milk of cows fed a TMR. Although we witnessed some defects associated with late fermentation in control and RF-DDGS cheeses, including occasional slits and blow holes, when observed as a whole, feeding RF-DDGS did not increase the 
propensity for defects, and we did not see any splits. The findings are consistent with our previous research (Manimanna Sankarlal et al., 2015), where feeding full-fat DDGS did not affect the quality of baby Swiss cheese produced compared with feeding a conventional dairy ration without DDGS to lactating Holstein dairy cows.

\section{CONCLUSIONS}

These results indicate that $20 \%$ RF-DDGS on a DM basis can be effectively included in the rations of lactating dairy cows without any adverse effects on milk composition or measured blood markers of energy balance. Our findings, however, indicate that the rations formulated with RF-DDGS resulted in increased DMI for cows fed RF-DDGS and consequently decreased feed efficiency. These findings indicate promising prospects for the utilization of RF-DDGS, which are often more economical than traditional protein sources. In addition, our results may indicate that feeding RF-DDGS, at least when supplemental rumen-protected lysine is provided, may lead to improved dietary protein utilization compared with soybean-based protein without compromising the composition of milk. However, because actual lysine content was not measured, further studies would be needed to confirm this explanation. Furthermore, there were no differences in suitability of milk used for baby Swiss cheese because there was practically no difference in quality of cheese produced from milk from cows fed RF-DDGS and their control counterparts.

\section{ACKNOWLEDGMENTS}

This article is a product of the Iowa Agriculture and Home Economics Experiment Station (Ames, IA). Project no. IOW04002 was sponsored by Hatch Act and State of Iowa funds. We are grateful for the funding provided by the Minnesota Corn Growers Association (Shakopee, MN) and Midwest Dairy Association (St. Paul, MN) to support this research. In addition, we thank the personnel at the Iowa State University Dairy Farm (Ames) for their assistance in coordinating and implementing the logistics of performing the work described herein. We are particularly grateful to the many undergraduate assistants, particularly Claire Collins and Mericia Boutchee, who provided labor and care of the research animals, sample collection, and cheese making. We appreciate Leo Timms for technical assistance on the project and Cristina Duran and Soi Meng Lei for their assistance in the analytical portions of this research. Cultures were generously donated by Dupont Danisco (New Century, KS). Proximate analysis of cheese was graciously conducted at South Dakota State University (Brookings, SD). We also thank Amber Testroet (Iowa State University, Ames) for her assistance with the preparation of this manuscript. Finally, we acknowledge the time and expertise provided by our trained panelists.

\section{REFERENCES}

Abdelqader, M. M., A. R. Hippen, K. F. Kalscheur, D. J. Schingoethe, and A. D. Garcia. 2009. Isolipidic additions of fat from corn germ, corn distillers grains, or corn oil in dairy cow diets. J. Dairy Sci. 92:5523-5533

Anderson, J. L., D. J. Schingoethe, K. F. Kalscheur, and A. R. Hippen. 2006. Evaluation of dried and wet distillers grains included in two concentrations in the diets of lactating dairy cows. J. Dairy Sci. 89:3133-3142.

AOAC International. 2016. Official Methods of Analysis. 20th ed. AOAC Int., Gaithersburg, MD.

Atherton, H. V., and J. A. Newlander. 1977. Chemistry and Testing of Dairy Products. 4th ed. AVI, Westport, CT.

Bauman, D. E., and J. M. Griinari. 2001. Regulation and nutritional manipulation of milk fat: Low-fat milk syndrome. Livest. Prod. Sci. 70:15-29.

Baumgard, L. H., J. K. Sangster, and D. E. Bauman. 2001. Milk fat synthesis in dairy cows is progressively reduced by increasing supplemental amounts of trans-10, cis-12 conjugated linoleic acid (CLA). J. Nutr. 131:1764-1769.

Bryant, A. M. 1964. Variations in the $\mathrm{pH}$ and volatile fatty acid concentration within the bovine reticulo-rumen. N. Z. J. Agric. Res. 7:694-706.

Cakir, E., and S. Clark. 2009. Swiss cheese and related products. Pages 438-454 in The Sensory Evaluation of Dairy Products. S. Clark, M. Costello, M. Drake, and F. Bodyfelt, ed. Springer, New York, NY.

Castillo-Lopez, E., H. A. Ramirez-Ramirez, T. J. Klopfenstein, D. Hostetler, K. Karges, S. C. Fernando, and P. J. Kononoff. 2014. Ration formulations containing reduced-fat dried distillers grains with solubles and their effect on lactation performance, rumen fermentation, and intestinal flow of microbial nitrogen in Holstein cows. J. Dairy Sci. 97:1578-1593.

Drewnoski, M. E., P. Doane, and S. L. Hansen. 2014. Ferric citrate decreases ruminal hydrogen sulphide concentrations in feedlot cattle fed diets high in sulphate. Br. J. Nutr. 111:261-269.

Erdman, R. A., S. Piperova, and R. A. Kohn. 2011. Corn silage versus corn silage:alfalfa hay mixtures for dairy cows: Effects of dietary potassium, calcium, and cation-anion difference. J. Dairy Sci. 94:5105-5110.

Fröhlich-Wyder, M., H. P. Bachmann, and M. G. Casey. 2002. Interaction between propionibacteria and starter/non-starter lactic acid bacteria in Swiss-type cheeses. Lait 82:1-15.

Guggisberg, D., P. Schuetz, H. Winkler, R. Amrein, E. Jakob, M.-T. Fröhlich-Wyder, S. Irmler, W. Bisig, I. Jerjen, M. Plamondon, J. Hofmann, A. Flisch, and D. Wechsler. 2015. Mechanism and control of the eye formation in cheese. Int. Dairy J. 47:118-127.

Harrison, J., R. White, R. Kincaid, E. Block, T. Jenkins, and N. St. Pierre. 2012. Effectiveness of potassium carbonate sesquihydrate to increase dietary cation-anion differences in early lactation cows. J. Dairy Sci. 95:3919-3925.

Houck, K. B., W. L. Wendorff, and R. M. Kaiser. 2007. Disillers grains can add nutrition - and spores. Dairy Pipeline 19:4-6.

Hu, W., M. R. Murphy, P. D. Constable, and E. Block. 2007. Dietary cation-anion difference and dietary protein effects on performance and acid-base status of dairy cows in early lactation. J. Dairy Sci. 90:3355-3366.

Kleinschmit, D. H., D. J. Schingoethe, K. F. Kalscheur, and A. R. Hippen. 2006. Evaluation of various sources of corn dried distillers grains plus solubles for lactating dairy cattle. J. Dairy Sci. 89:4784-4794. 
Klopfenstein, T. J., G. E. Erickson, and V. R. Bremer. 2008. Board invited review: Use of distillers by-products in the beef cattle feeding industry. J. Anim. Sci. 86:1223-1231.

Kosikowski, F. V., and V. V. Mistry. 1997. Cheese and Fermented Milk Foods: Volume II. Procedures and Analysis. F. V. Kosikowski, Westport, CT.

Maia, M. R. G., L. C. Chaudhary, L. R. Figueres, and J. R. Wallace. 2007. Metabolism of polyunsaturated fatty acids and their toxicity to the microflora of the rumen. Antonie Van Leeuwenhoek 91:303-314.

Majoni, S., T. Wang, and L. A. Johnson. 2011. Physical and chemical processes to enhance oil recovery from condensed corn distillers solubles. J. Am. Oil Chem. Soc. 88:425-434.

Manimanna Sankarlal, V., E. D. Testroet, D. C. Beitz, and S. Clark. 2015. Dried distillers grains with solubles do not always cause late blowing in baby Swiss cheese. J. Dairy Sci. 98:8545-8553.

Marshall, R. T. 1992. Standard Methods for the Examination of Dairy Products. 16th ed. American Public Health Association, Washington, DC.

Mertens, D. R. 2002. Gravimetric determination of amylase treated neutral detergent fiber in feeds with refluxing in beakers or crucibles: Collaborative study. J. AOAC Int. 85:1217-1240.

Mjoun, K., K. F. Kalscheur, A. R. Hippen, and D. J. Schingoethe. 2010. Performance and amino acid utilization of early lactation dairy cows fed regular or reduced-fat dried distillers grains with solubles. J. Dairy Sci. 93:3176-3191.

National Research Council (NRC). 2001. Nutrient Requirements of Dairy Cattle. 7th rev. ed. National Academies Press, Washington, DC.

O'Sullivan, D. J., P. L. H. McSweeney, P. D. Cotter, L. Giblin, and J. J. Sheehan. 2016. Compromised Lactobacillus helveticus starter activity in the presence of facultative heterofermentative Lactobacillus casei DPC6987 results in atypical eye formation in Swiss-type cheese. J. Dairy Sci. 99:2625-2640.

Paz, H. A., and P. J. Kononoff. 2014. Lactation responses and amino acid utilization of dairy cows fed low-fat distillers dried grains with solubles with or without rumen-protected lysine supplementation. J. Dairy Sci. 97:6519-6530.

Peterson, D. G., E. A. Matitashvili, and D. E. Bauman. 2003. Diet-induced milk fat depression in dairy cows results in increased trans-10 cis-12 CLA in milk fat and coordinate suppression of mRNA abundance for mammary enzymes involved in milk fat synthesis. J. Nutr. 133:3098-3102.
Pritchard, R. H. 2010. Use of de-oiled dried distillers grains as a source of crude protein in finishing cattle diets. South Dakota Beef Report. Paper 3. Accessed Apr. 2017. http://openprairie.sdstate .edu/sd_beefreport_2010/3.

Ramirez-Ramirez, H. A., E. Castillo-Lopez, C. J. R. Jenkins, N. D. Aluthge, C. Anderson, S. C. Fernando, K. J. Harvatine, and P. J. Kononoff. 2016. Reduced-fat dried distillers grains with solubles reduces the risk for milk fat depression and supports milk production and ruminal fermentation in dairy cows. J. Dairy Sci. 99:1912-1928

Ramos, M. J., C. M. Fernandez, A. Casas, L. Rodriguez, and A. Perez. 2009. Influence of fatty acid composition of raw materials on biodiesel properties. Bioresour. Technol. 100:261-268.

Sasikala-Appukuttan, A. K., D. J. Schingoethe, A. R. Hippen, K. F. Kalscheur, K. Karges, and M. L. Gibson. 2008. The feeding value of corn distillers solubles for lactating dairy cows. J. Dairy Sci. 91:279-287.

Schingoethe, D. J., K. F. Kalscheur, A. R. Hippen, and A. D. Garcia 2009. Invited review: The use of distillers products in dairy cattle diets. J. Dairy Sci. 92:5802-5813.

Shen, J. S., Z. Chai, L. J. Song, J. X. Liu, and Y. M. Wu. 2012. Insertion depth of oral stomach tubes may affect the fermentation parameters of ruminal fluid collected in dairy cows. J. Dairy Sci. 95:5978-5984.

Shreve, B., N. Thiex, and M. Wolf. 2006. National Forage Testing Association Reference Method NFTA Method 2.1.4-Dry matter by oven drying for $3 \mathrm{hr}$ at 105C. Accessed Mar. 29, 2018. http://www .foragetesting.org/files/NFTAReferenceMethodDM-09-18-06.pdf.

Sukhija, P. S., and D. L. Palmquist. 1988. Rapid method of determination of total fatty acid content in composition of feedstuffs and feces. J. Agric. Food Chem. 36:1202-1206.

White, S. R., J. R. Broadbent, C. J. Oberg, and D. J. McMahon. 2003. Effect of Lactobacillus helveticus and Propionibacterium freudenrichii ssp. shermanii combinations on propensity for split defect in Swiss cheese. J. Dairy Sci. 86:719-727.

Wildman, C. D., J. W. West, and J. K. Bernard. 2007. Effects of dietary cation-anion difference and potassium to sodium ratio on lactation dairy cows in hot weather. J. Dairy Sci. 90:970-977.

Zinn, R. A. 1989. Influence of level and source of dietary fat on its comparative feeding value in finishing diets for feedlot steers. J. Anim. Sci. 67:1038-1049. 